\title{
Conformational analysis of peptides derived from the BRI gene
}

\author{
Victor Lelyveld ${ }^{\mathrm{a}}$, Omar El-Agnaf ${ }^{\mathrm{a}, 1}$, Giuliano Siligardi ${ }^{\mathrm{b}}$, Rohana Hussain ${ }^{\mathrm{b}}$, Parvez I. Haris ${ }^{\mathrm{c}}$, \\ Maria Lee ${ }^{\mathrm{a}}$ and Brian Austen ${ }^{\mathrm{a}, *}$ \\ ${ }^{a}$ Neurodegeneration Unit, St George's Hospital Medical School, Cranmer Terrace, London SW17 ORE, \\ $U K$ \\ ${ }^{\mathrm{b}}$ Department of Pharmacy, King's College, Franklin-Wilkins Building, 150 Stamford Street, London \\ SE1 8WA, UK \\ ${ }^{\mathrm{c}}$ Department of Biological Sciences, De Montfort University, The Gateway, Leicester LE1 9BH, UK
}

\begin{abstract}
The 34-residue peptides (ABri and ADan) derived from the $3^{\prime}$ end of the gene BRI which is mutated in British and Danish families with dementia, have been synthesized, with and without the predicted intramolecular disulphides. CD measurements show that the oxidised and reduced forms have tendencies to adopt $\beta$-structure at neutral $\mathrm{pH}$ with prolonged time of incubation. The shift to $\beta$-structure is accompanied by oligomer formation. The neurotoxic properties of these oligomers in vitro may explain the cognitive decline seen in the patients. Structural analyses will be useful in the design of therapeutic drugs.
\end{abstract}

\section{Introduction}

Familial British dementia (FBD) and familial Danish dementia (FDD) are rare autosomal dominant neurodegenerative disorders that share features of Alzheimer's disease (AD), including amyloid plaques surrounded by astrocytes and microglia, neurofibrillary tangles, neuronal loss and progressive dementia $[1,2]$. FBD is clinically characterized by the onset of dementia in the fifth decade, progressive spastic tetraparesis and cerebellar ataxia. FDD is similar, but also involves cataract formation and auditory loss. FBD and FDD are distinguished pathologically from AD and other dementing disorders by plaque deposition in the cerebellum and the accompanying cerebellar ataxia. These conditions were, however, previously reported as atypical forms of familial AD [3]. Histological studies show that some of the amyloid deposits in FBD patients exhibit yellow-green birefringence under polarized light after staining with Congo red, indicating the presence of amyloid-like fibrils with $\beta$-sheet structure [4]. Immunohistochemical and biochemical analysis of plaques and vascular amyloid of FBD and FDD brains revealed that a $\sim 4 \mathrm{kDa}$ peptides named ABri and ADan are the main components of the highly insoluble amyloid deposits likely to be involved in pathogenesis [4].

The ABri peptide was determined to be a fragment derived from a larger, membrane-anchored precursor protein, termed BRI precursor protein, encoded by the BRI gene on chromosome 13 [4]. Wild-type BRI protein has 266 amino acid residues, whereas FBD patients have a single nucleotide transition $(\mathrm{T} \rightarrow \mathrm{A})$ that converts the stop codon (TGA) into AGA. This mutation changes the length of the BRI

\footnotetext{
${ }^{1}$ Present address: Department of Biological Sciences, University of Lancaster, Lancaster LA1 4YQ, UK.

*Corresponding author: Tel.: +44 208725 5651; Fax: +44 208725 3594; E-mail: sghk200@sghms.ac.uk.
} 


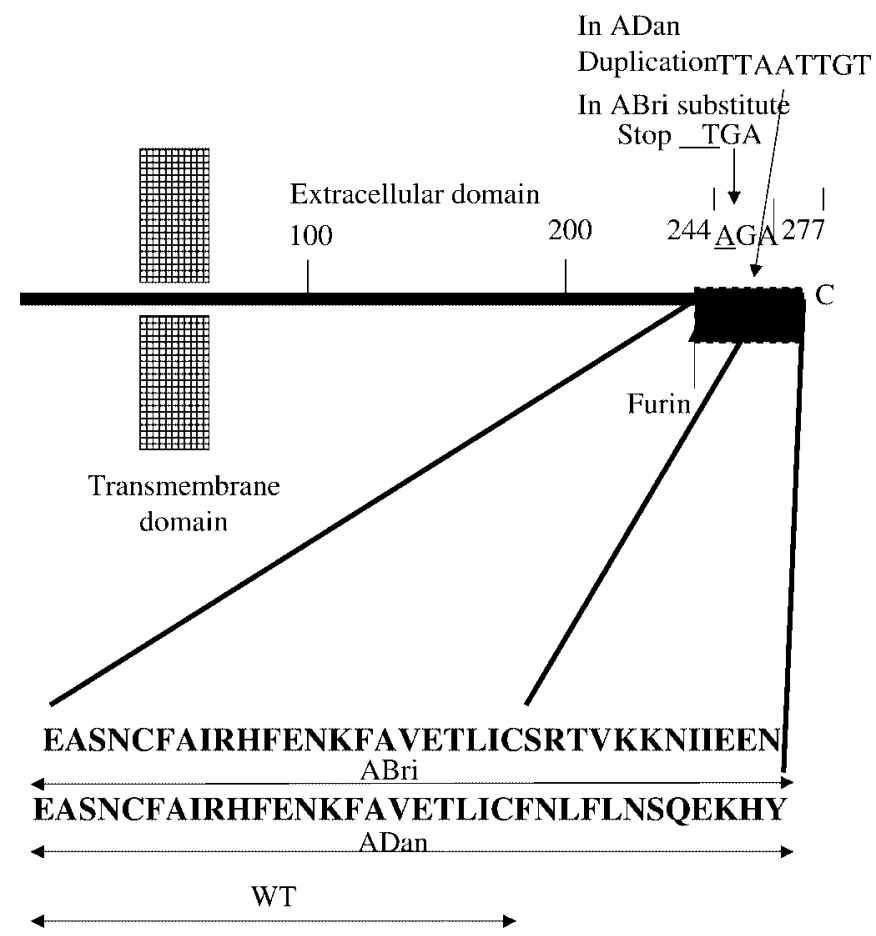

Fig. 1. Representation of the precursor protein and amyloid peptides ABri and ADan in patients affected with FBD and FDD. One ten base insertion in ADan leads to the expression of a 277-residue protein BRI, which is processed to release the 34-residue peptide ADan. A single-base substitution at the stop codon of the BRI gene in FBD changes a stop codon to an Arg-reading codon and the expression of a 277-residue protein which is processed to yield the 34-residue peptide ADan. The normal termination codon gives a protein of 266 residues and cleavage by furin releases the normal WT peptide of 23 residues, which are also found as the $\mathrm{N}$-terminal 23 residues of ABri and ADan.

precursor protein to 277 amino acids (Fig. 1) [4]. Furin-mediated endoproteolytic processing of mutant BRI between Arg243 and Glu244 produces the 34 carboxy-terminal residue fragment, ABri peptide (Fig. 1) [5]. Cells transfected with the wild-type or mutant BRI gene were found to produce $\sim 3 \mathrm{kDa}$ or $\sim 4 \mathrm{kDa}$ peptides corresponding to cleaved WT peptide and ABri, respectively [5]. Notably, the cells transfected with the mutant BRI produced more peptide than those transfected with the wild-type, indicating that the carboxy-terminal extension enhances furin proteolysis [5].

A decamer duplication in the $3^{\prime}$ region of the BRI gene originates an amyloid peptide that is associated with dementia in FDD [6]. The resulting reading frame is also extended to 277 amino acid residues, and cleavage by furin releases a peptide of 34 residues, which is identical to ABri and WT in its N-terminal 22-residues, but contains a C-terminal 10 residues composed of hydrophobic and basic residues (Fig. 1). Staining of post-mortem sections with an antibody to ADan reveal both Congo red-positive deposits in parenchymal and vascular lesions as well as Congo-red-negative deposits in the hippocampus and subiculum [5]. In the CA4 region of hippocampus, most immunoreactive deposits were Congo red-negative, and had a cotton-wool ball appearance.

The appearance of ABri and ADan in pathological lesions found in regions of the central nervous system most affected in FBD and FDD implies that their accumulation is related to the pathogenesis of FBD and FDD. As $\beta$-amyloid deposition is very similar in Alzheimer's disease (AD), understanding the properties of ABri and ADan and their role in the pathogenesis of FBD and FDD may shed light on the cause of dementia in the much more common AD. 


\section{Methods}

\subsection{Peptide synthesis}

ABri, ADan and WT were synthesised using Fmoc/tBu chemistry recently optimised for the synthesis of amyloids [7] using HATU activation with selected hindered residues on Fmoc Asn(tBoc)-PEG-PS, Fmoc Ser(tBu)-PEG-PS and Fmoc Tyr(tBu)-PEG-PS supports (ABI systems, Cheshire, UK) on a Milligen 9050 synthesizer, Deprotected peptides were released by treatment with TFA and scavengers, triturated in ether and purified on preparative HLPC on a Vydac C4 $(250 \times 22 \mathrm{~mm}) 214 \mathrm{TP} 1022$ column, eluting with a gradient of acetonitrile. Purity of peptides was judged to be $>95 \%$ by analytical HPLC on a column $(250 \times 4.6 \mathrm{~mm})$ of Phenomenix Jupiter C3 in $0.1 \%$ TFA eluting with a gradient of acetonitrile, and by electrospray and Malditof mass spectrometry. The MW of reduced ABri was found to be 3955.5, reduced WT 2629.23 and reduced ADan 4620, identical to calculated masses. As the sequence of the BRI protein predicts the possibility of intramolecular disulphide bonds in its C-terminal region, we produced the cyclic forms of the peptides by air oxidation. Lyophilisaed HPLC-purified peptides were dissolved in $0.1 \mathrm{M}$ ammonium bicarbonate at $\mathrm{pH} 8.0$ and $0.1 \mathrm{mg} / \mathrm{ml}$ and stirred for two days at room temperature in contact with air. The oxidation was monitored by analytical HPLC from the disappearance of the reduced form and appearance of the oxidised form, and by the loss of 2 mass units seen by analyses by Malditof mass spectrometry. The production of cyclic forms was confirmed by the differential appearance of tryptic fragments seen on Malditof mass spectrometry, only the reduced forms showed the predicted fragments containing reduced Cys residues.

\subsection{Circular Dichroism (CD) spectroscopy}

Spectra were recorded using nitrogen-flushed JASCO J720 and J600 spectropolarimeters, and scans were obtained using $4 \mathrm{sec}$ time constant, $10 \mathrm{~nm} / \mathrm{min}$ scan speed and a spectral band width of $2 \mathrm{~nm}$. Both spectropolarimeters were calibrated with ammonium D-camphor-10-sulfonate. Quartz cells of $0.02 \mathrm{~cm}$ and $1 \mathrm{~cm}$ were used for measurements in the far-UV $(185-250 \mathrm{~nm})$ and near-UV $(250-350 \mathrm{~nm})$ regions, respectively. CD spectra were reported as $\Delta \varepsilon=\varepsilon L-\varepsilon R\left(\mathrm{M}^{-1} \mathrm{~cm}^{-1}\right)$ based upon an average molecular weight per amino acid of 113 . UV spectrophotometry was used to determine the absolute concentration of peptides from calculated extinction coefficients in solution in order to calculate the differential molar extinction coefficient $\Delta \varepsilon$.

\subsection{Size Exclusion Chromatography (SEC) system}

At various time points, aliquots $(20 \mu \mathrm{l})$ solutions of ABri or ADan peptides incubated in $0.1 \mathrm{M}$ Tris$\mathrm{HCl}(\mathrm{pH} 9)$ were loaded on a superdex 75 column $(10 \times 270 \mathrm{~mm})$ and eluted with $0.1 \mathrm{M}$ Tris- $\mathrm{HCl}(\mathrm{pH} 9)$ at a flow rate of $0.5 \mathrm{ml} / \mathrm{min}$. Eluate was monitored at $215 \mathrm{~nm}$.

\subsection{Congo red birefringence}

Aged $100 \mu \mathrm{l}$ aliquots of aged WT ABri or ADan solutions were added to $900 \mu \mathrm{l}$ of Congo red solution $(2.5 \mathrm{mg} / 100 \mathrm{ml}$ in PBS $\mathrm{pH}$ 7.4). This mixture was incubated for $1 \mathrm{hr}$ at room temperature and then centrifuged at 100,000 rpm in a TL-100 Beckman centrifuge. The resultant pellet was placed on a slide and examined under polarizing light using an Nikon Optiphot light microscope under a $\times 10$ lens. 


\section{Results}

The oxidised cyclic form of $\mathrm{ABri} \mathrm{ABri}(\mathrm{OX})$ (Fig. 2a) peptide was found to be soluble in $\mathrm{H}_{2} \mathrm{O}$ at $\mathrm{pH} 4.3$ and above $\mathrm{pH} 9$, exhibiting cloudy solutions at intermediate $\mathrm{pHs}$. The $\mathrm{CD}$ changes during $\mathrm{pH}$ titration of ABriOX in $\mathrm{H}_{2} \mathrm{O}$ from $\mathrm{pH} 4.3$ to $\mathrm{pH} 9.4$ at incremental $\mathrm{pH}$ units showed a clear tendency of the peptide to fold into a $\beta$-strand type of conformation at $\mathrm{pH}$ values closer to $\mathrm{pH} 7$. At $\mathrm{pH} 4.3(t=0.5 \mathrm{~h})$, the peptide showed a U-type CD spectrum with a single negative band at about $200 \mathrm{~nm}$, characteristic of mainly irregular structure. On increasing the $\mathrm{pH}$, substantial conformational changes were observed. At $\mathrm{pH} 5.6$ $(t=1 \mathrm{~h})$, a negative CD band at about $212 \mathrm{~nm}$ becoming more positive at about $190 \mathrm{~nm}$ was indicative of a $\beta$-strand type of conformation being adopted. At $\mathrm{pH} 6.3(t=1.5 \mathrm{~h})$ and $\mathrm{pH} 7.2(t=2 \mathrm{~h})$, the CD spectra showed overall smaller intensities due to lower peptide solubility. After 24 hours incubation spectra all appeared $\beta$ in structure but at lower intensity because more of the peptide had precipitated (Fig. 2b). At pH 9.1, an increased solubility led to a CD spectrum quite different in shape but as intense as that observed at pH 4.3 (Fig. 2a) and characteristic of $\beta$-structure. In contrast the WT Bri peptide showed $\mathrm{CD}$ characteristic of only random structure at all $\mathrm{pH}$ values tested with minima at lower wavelength (203 nm) (Fig. 2c).

$\mathrm{ADan}(\mathrm{Ox})$ showed a red shift of the crossover at about $205 \mathrm{~nm}$ as the peptide began to associate/aggregate (Fig. 3a). At all $\mathrm{pH}$ values it showed spectra characteristic of $\beta$-sheet. As the aggregation was broken by incubation at $\mathrm{pH} 7.6$, light scattering was decreased and the cross-over shifted back. In the more hydrophobic acetonitrile environment, ADan (oxid) was more helical in structure (Fig. 3b). Moreover, this structure was stable showing no CD changes with time. This environment may be more akin to that experienced by the fragment in a membranous cellular environment, where it may be stabilized into a conformation that has no propensity to aggregate. When ADan is released by furin action, it may
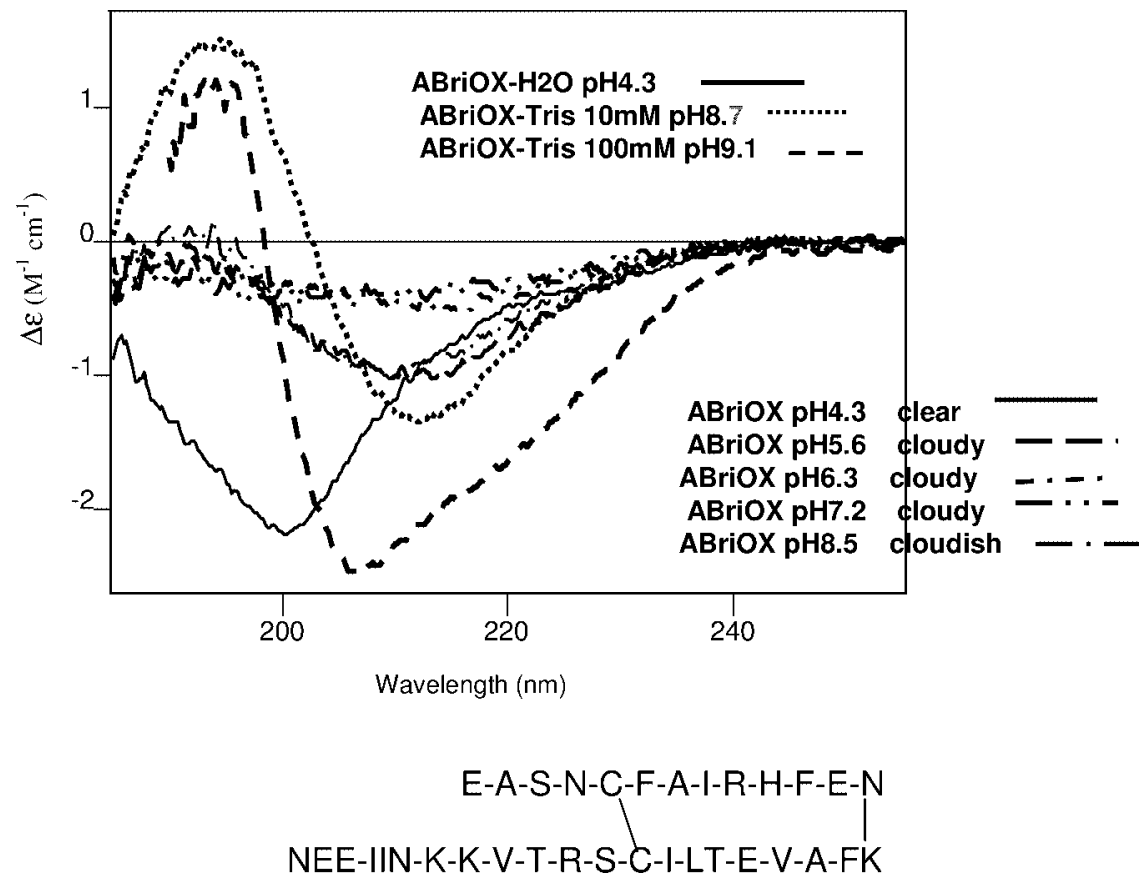

Fig. 2a. The CD spectra of mutant ABri (oxidised) at various $\mathrm{pH}$ values. The peptide was dissolved at $\mathrm{pH} 4.3$ in water, and adjusted to the pHs shown by the addition of Tris and sodium hydroxide solutions, CD spectra were measured immediately. 


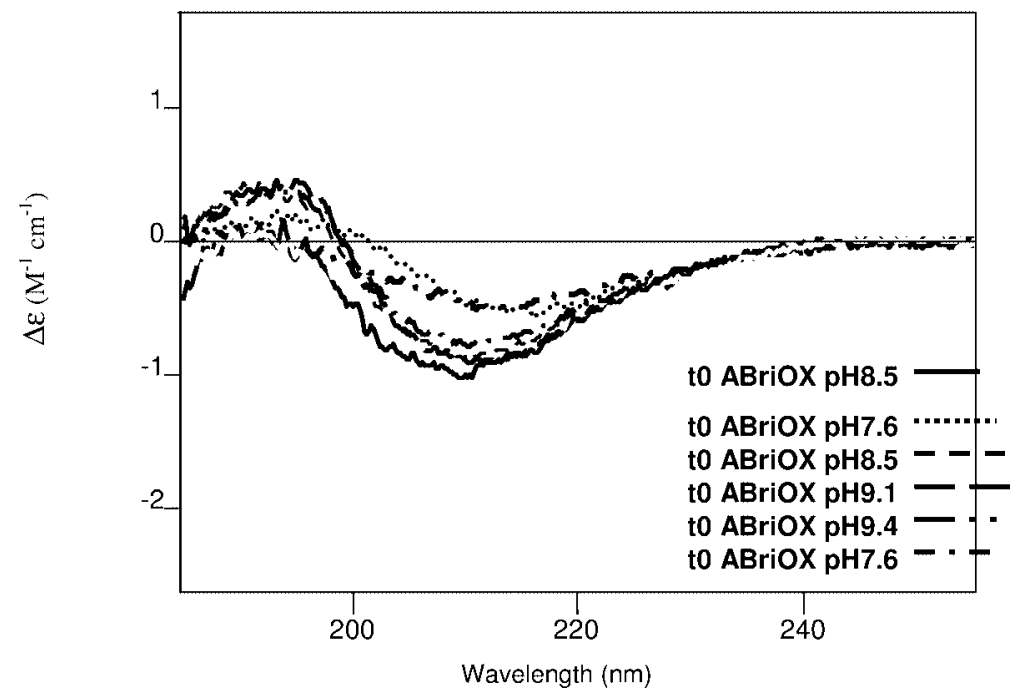

Fig. 2b. The CD spectra of mutant ABri (oxidised) at various $\mathrm{pH}$ values after 24 hours incubation at room temperature.

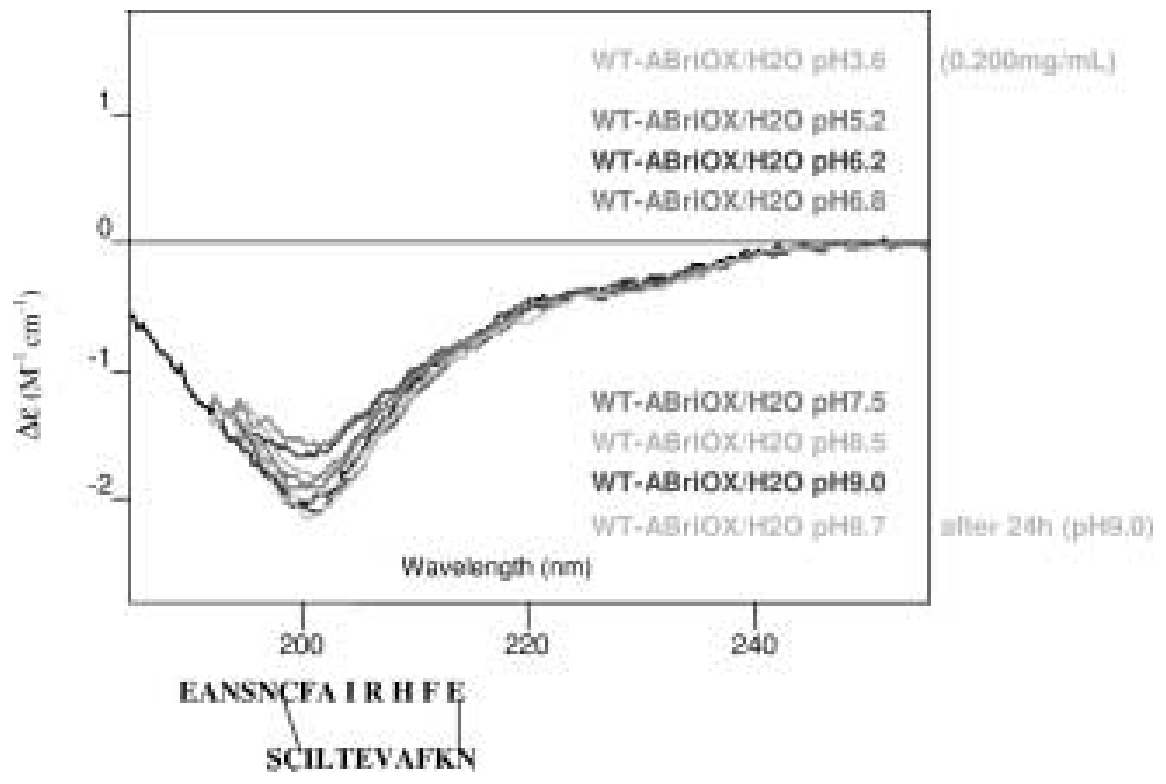

Fig. 2c. The CD spectra of WT ABri (oxidised) at various $\mathrm{pH}$ values.

migrate to the more aqueous extracellular environment where it would start to adopt $\beta$-structure and then aggregate. If this is in brain, in the aggregated state it may start to attack and kill neurones.

In aqueous media, conformational changes were found to be not only $\mathrm{pH}$ but also time dependent (Fig. 4). The 2-week-aged ABri solutions at $\mathrm{pH} 8.5$ showed a positive CD band centred at about $192 \mathrm{~nm}$ though the negative band at $212 \mathrm{~nm}$ remained similar to those observed at $\mathrm{pH} 5.6$ and 8.5. This can be illustrated by the $212 / 192$ ratio that reflects the rearrangements of the $\beta$-strand aggregation with time. Both backbone and aromatic/disulphide regions of the oxidised cyclic peptide ABriOX exhibited a distinct conformational behaviour with buffer environment and time (Fig. 4) compared with its fragment 


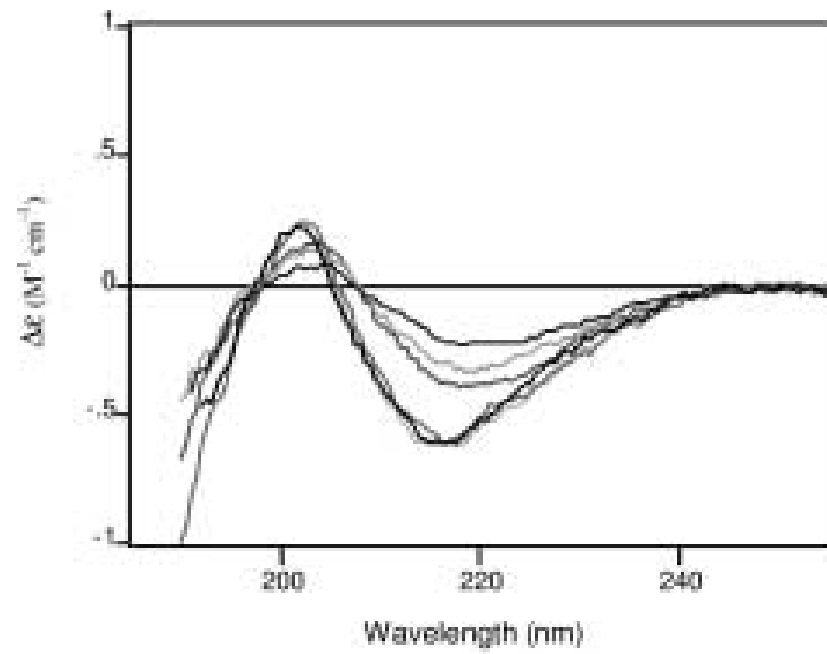

ADanOX pH5.9

ADanOX pH2.5

ADanOX pH4.1

ADmoX pHiti

ADanOX $\mathrm{pH} 7.6$ 48h

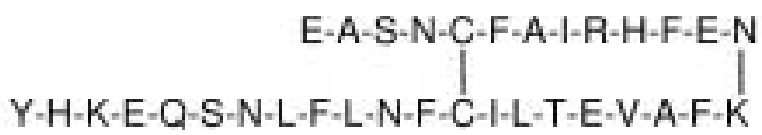

Fig. 3a. CD spectra of ADan (oxidised) at various $\mathrm{pH}$ values.
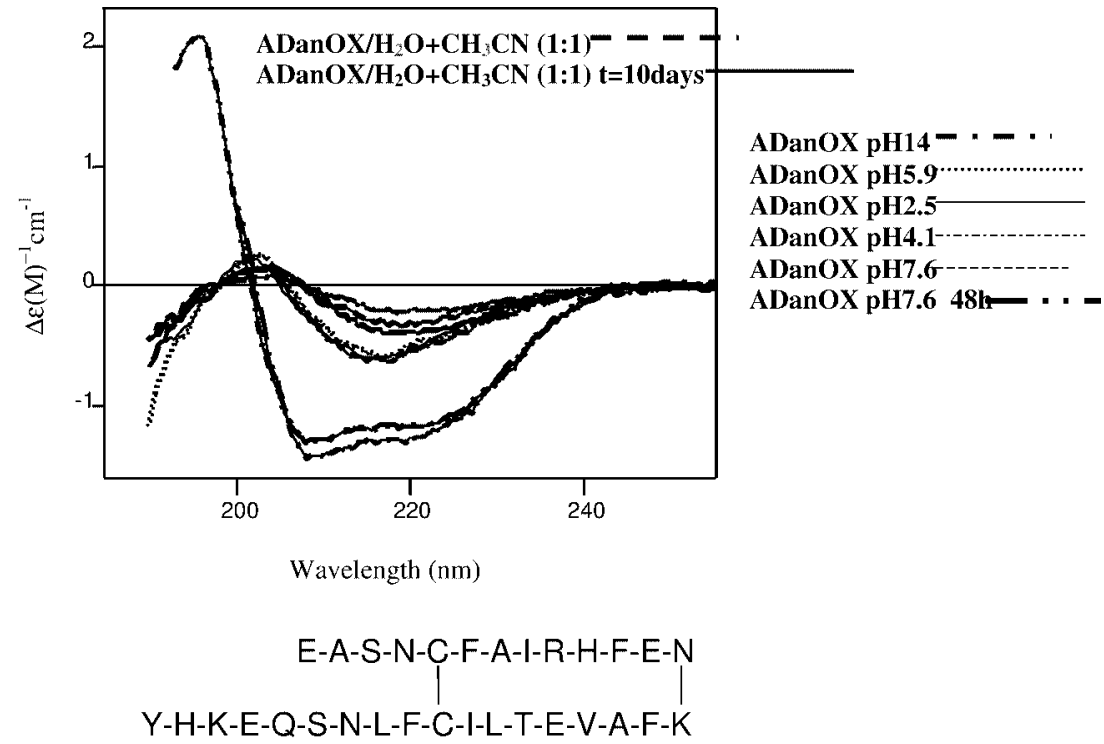

Fig. 3b. CD spectra of ADan (oxidised) at various values of $\mathrm{pH}$ in water and buffers, and in acetonitrile/water mixtures. The peptide was dissolved either directly in acetonitrile-water, or in dilute $\mathrm{NaOH}$ at $\mathrm{pH} 14$, and adjusted to lower $\mathrm{pH}$ values by addition in Tris and $\mathrm{HCl}$. ADan (Ox) was not completely soluble in acetonitrile-water mixture, and the spectra were normalised to equivalent concentrations based on their UV absorbances. 

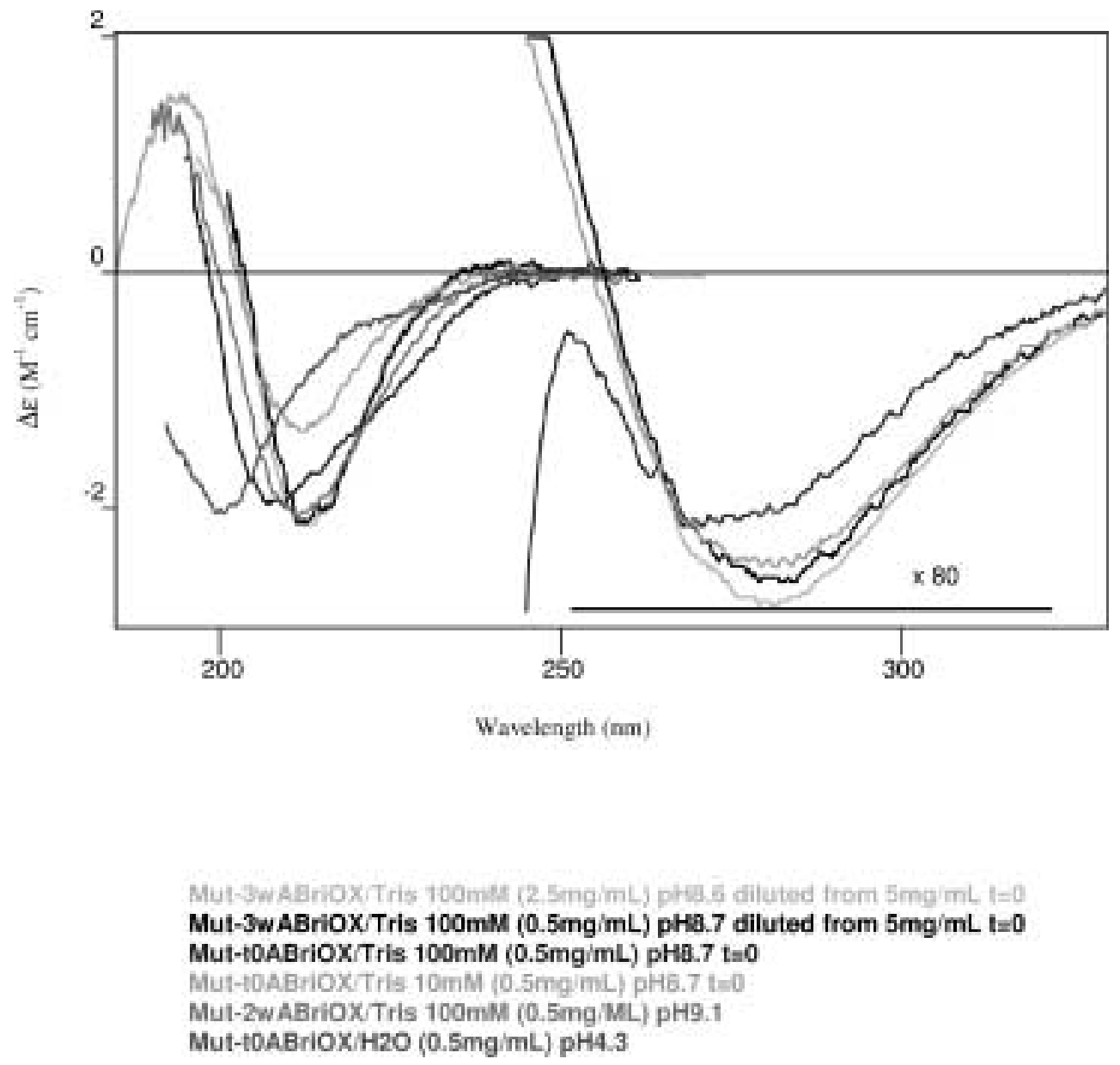

Fig. 4. Time and buffer changes of the CD spectra of oxidised ABri. Oxidised ABri was dissolved at $\mathrm{pH}$ 9, and either aged by incubating for 2 or 3 weeks at $37^{\circ} \mathrm{C}$ and $5 \mathrm{mg} / \mathrm{ml}$ then diluted 1 to 10 with water prior to $\mathrm{CD}$ measurements, or acidified by addition of $\mathrm{HCl}$, to the $\mathrm{pH}$ values shown, then aged and diluted.

wt-ABriOX (data not shown). Freshly prepared ABriOX $(0.5 \mathrm{mg} / \mathrm{ml})$ t0-mut-ABriOX) showed different $\mathrm{CD}$ profiles as a function of Tris buffer concentration (Fig. 4). In Tris $10 \mathrm{mM}, \mathrm{pH}$ 8.7, the peptide t0-mut-ABriOX showed a backbone CD spectrum of $\beta$-structure that tentatively we have related to a three-antiparallel $\beta$-strand main component. This assignment is based on the close resemblance with the CD spectra of monoclonal antibody Fab domain and minibody [8], of which, the main structural motive is the repetition of four-antiparallel $\beta$-strands. In Tris $100 \mathrm{mM}, \mathrm{pH} 8.7, \mathrm{t} 0$-mut-ABriOX $(0.5 \mathrm{mg} / \mathrm{ml})$ showed another type of backbone CD spectrum that we have tentatively related to a two-antiparallel $\beta$-strands main component due to its similarity with the spectrum of gramicidin S [9]. Gramicidin $\mathrm{S}$ is a cyclic decapeptide that adopts two-antiparallel $\beta$-strands between two $\beta$-turns.

Whether these assignments are correct remain to be ascertained, however they help to visualise the conformational behaviour of this peptide. The different conformational states adopted under $10 \mathrm{mM}$ and $100 \mathrm{mM}$ Tris buffer conditions appear to converge with time towards a common third conformational state still of $\beta$-structure type. The two-week ( $2 \mathrm{~W}$-mut-ABriOX, $0.5 \mathrm{mg} / \mathrm{ml}$ diluted from $5 \mathrm{mg} / \mathrm{ml}$ ) and the three-week ( $3 \mathrm{~W}$-mut-ABriOX, $5 \mathrm{mg} / \mathrm{ml}$ and $0.5 \mathrm{mg} / \mathrm{ml}$ diluted from $5 \mathrm{mg} / \mathrm{ml}$ ) incubated peptides 
in Tris $100 \mathrm{mM}, \mathrm{pH} 8.7$, and the three-week aged t0-mut-ABriOX $(0.5 \mathrm{mg} / \mathrm{ml})$ in Tris $10 \mathrm{mM}$ showed similar backbone CD spectra (Fig. 4). The spectra were characterized by a negative CD band centered at about $212 \mathrm{~nm}$ with crossovers between 200 and $202 \mathrm{~nm}$. Qualitatively, these features are similar to those observed in Tris $10 \mathrm{mM}$ but differences in terms of magnitude and 212/192 ratio are supporting the view of a distorted type of three- $\beta$-strand motive. This is consistent with the $\mathrm{pH}$ titration data of mut-ABriOX (Figs $2 \mathrm{a}$ and $2 \mathrm{~b}$ ) where the differences in magnitude, crossover and 212/192 ratios have been ascribed to conformational rearrangements.

\section{Size-exclusion chromatography}

An additional analytical technique that showed changes in conformation of the peptides with time was size-exclusion chromatography on superdex 75. Fresh solutions of ADan chromatographed in $0.1 \mathrm{M}$ Tris ( $\mathrm{pH}$ 9.0) gave principally one small molecular weight peak, which from calibration of the column suggested a molecular weight of about $8 \mathrm{kDa}$, corresponding to a dimer (El-Agnaf et al., 2001) (Fig. 5). After aging the solutions at $\mathrm{pH} 9.0$, a considerable increase in the amount of higher molecular weight material ( $>76 \mathrm{kDa}$ was produced, with parallel loss of the low molecular weight material. Similar results have been obtained previously for ABri (El-Agnaf et al., 2001). The loss of overall material after prolonged aging was due to precipitation.

Precipitates were collected by centrifugation at $100,000 \times g$ stained with Congo red and viewed through polarisers fitted to a light microscope. Both oxidised ADan and ABri yielded material that gave a greenish birefringence (Fig. 6) and (El-Agnaf et al., 2000) with Congo red.

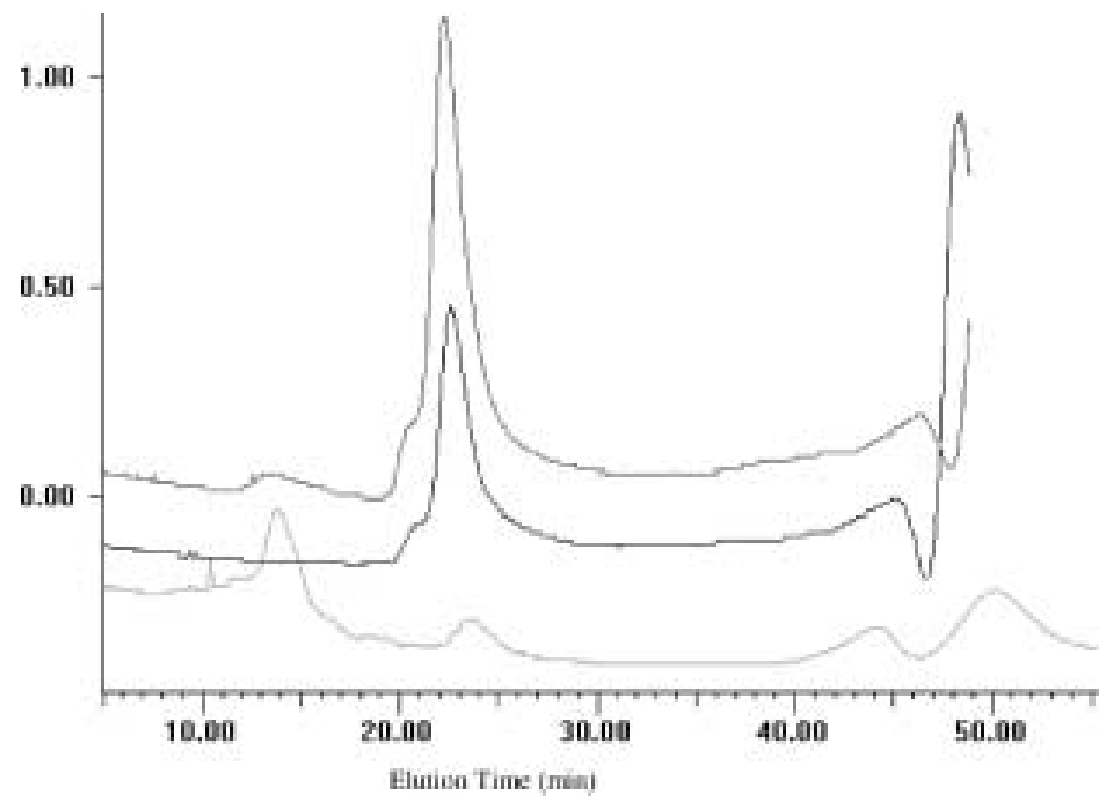

Fig. 5. Size-exclusion chromatography on a column of superdex 75, of ADan (oxid) freshly dissolved in water (top trace) at $6 \mathrm{mg} / \mathrm{ml}$, or and after 24 incubation at $37^{\circ} \mathrm{C}$ (middle trace). The bottom trace shows a freshly prepared solution at $0.6 \mathrm{mg} / \mathrm{ml}$. 


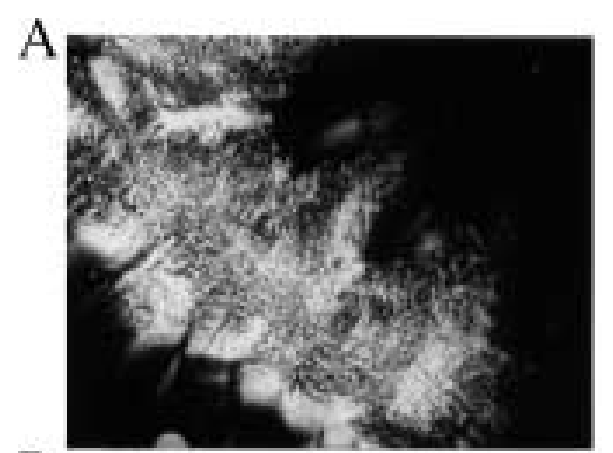

B

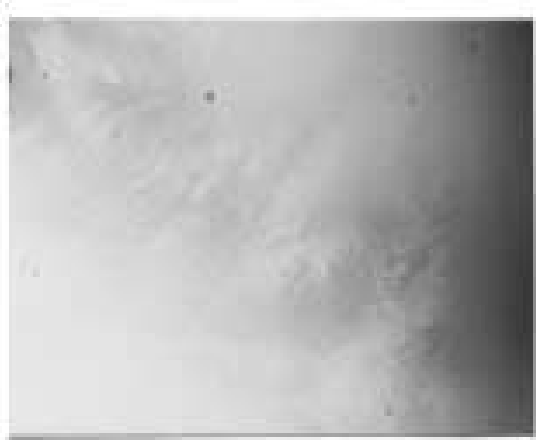

C

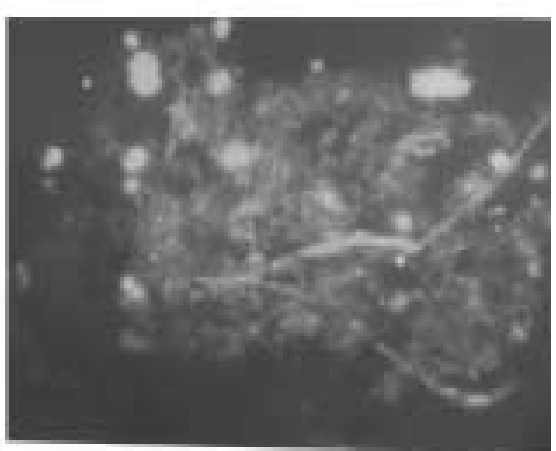

D

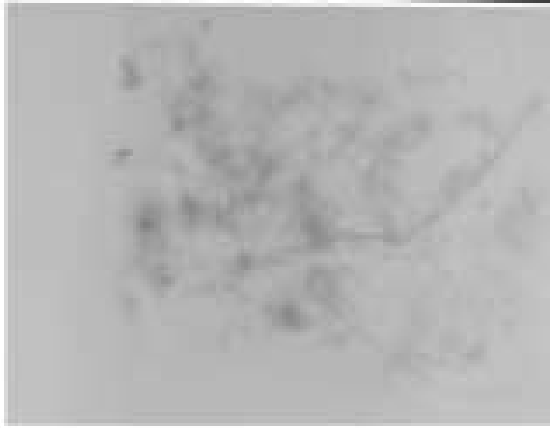

Fig. 6. Congo red stained preparations $\mathrm{ABri}(\mathrm{A}, \mathrm{B})$ or $\mathrm{ADan}(\mathrm{C}, \mathrm{D})$ viewed under polarisers turned to give maximum birefringence $(A, C)$ or minimum birefringence $(B, D)$ under a $\times 10$ lens of a Nikon Optiphot microscope.

\section{Discussion}

\subsection{An intramolecular disulfide bond in ABri}

The two cysteines in the peptide sequence of ABri led us to consider the possibility of disulfide bond formation in ADan and ABri. The reported molecular masses $(3,935.5)$ of ABri isolated from FDB brain or transfected cells [4] agreed exactly with the formation of an intramolecular disulfide bridge and cyclization of the N-terminal glutamyl residue to pyroglutamyl. The circulating form of ABri also agrees with the formation of the disulphide, but no pyroglu formation (Ghiso et al., 2001) whereas the mass spec analysis of brain-derived ADan was in agreement with a reduced peptide [6]. CD and FTIR spectroscopy were used to study the conformational preferences of the ABri and WT peptides. Freshly prepared oxidised ABri and ADan solutions display $\mathrm{CD}$ spectra that are consistent with predominantly $\beta$-sheet structure. In contrast, fresh solutions of WT lacked significant structure. Furthermore, only ABri solutions showed random coil to $\beta$-sheet transition on increasing the $\mathrm{pH}$ from 4 to 9 .

The transition observed into $\beta$-sheet conformation occurring upon aging of WT solutions for three weeks was less marked, and the amount of $\beta$-sheet in aged WT solution was less than in aged ABri solution as observed by CD and FTIR. Changes in the microenvironment of the disulfide and phenylalanine residues was only evident in the aged ABri solution, from the analysis of the CD changes in the 250-280 nm region.

Additional studies showed that the adoption of $\beta$-sheet conformation coincided with oligomerisation. Size exclusion chromatography showed that oligomers of MW $>75 \mathrm{kDa}$ were rapidly formed in Tris solutions of oxidised ABri and ADan (El-Agnaf et al., 2001). Electrophoresis in Tris-tricine highly cross- 
linked polyacrylamide gels also showed that a range of increasing size oligomers were formed that were stable to SDS (El-Agnaf et al., 2001).

\subsection{Molecular model of ABri}

Multiple alignment secondary structure predictions of uncleaved BRI-encoded proteins $(26,27)$ predicted a $\beta$-strand-turn-strand structure in the $\mathrm{N}$-terminal 23 residues of ABri (El-Agnaf et al., 2001). This region was modelled in this conformation, with a constraining intramolecular disulfide bond between Cys5 and Cys 22 of ABri accommodated in a long $\beta$-hairpin $\left(\mathrm{C}_{5}\right.$ FAIRHFENKFAVETLIC 22 ) stabilized by van der Waals' contacts and charge-charge interactions (El-Agnaf et al., 2001) Asn13 and Lys14 are statistically favorable $i+1$ and $i+2$ residues of a type I turn in this long disulfide $\beta$-hairpin. Further stabilization of this $\beta$-hairpin [15] was provided by side chain interaction between Glu18-Arg9 in a non-hydrogen bonding (NHB) position and between Phe11-Ala16 (in NHB position). The C-terminal sequence of ABri was extended as the third strand of a three stranded $\beta$-sheet, stabilized by van der Waals' contacts of NHB pairs, Val17-Ile30 and Ile21-Val26 and a charge-charge interaction between the carboxy-terminus and the Lys14 side chain. To accommodate this third anti-parallel strand, we placed another type I $\beta$-turn at the sequence Cys22-Ser23-Arg24-Thr25. ADan was superimposed upon the model of ABri recently published (El-Agnaf et al., 2001) by using the residue replacement and energy minimization functions of Swiss-PDB-viewer, and then three molecules of ADan in the three $\beta$-strand conformation were docked using the docking function (Fig. 7). The primary interactions holding the oligomeric state were modeled to be hydrophobic in nature, between the hydrophobic side-chains (col-

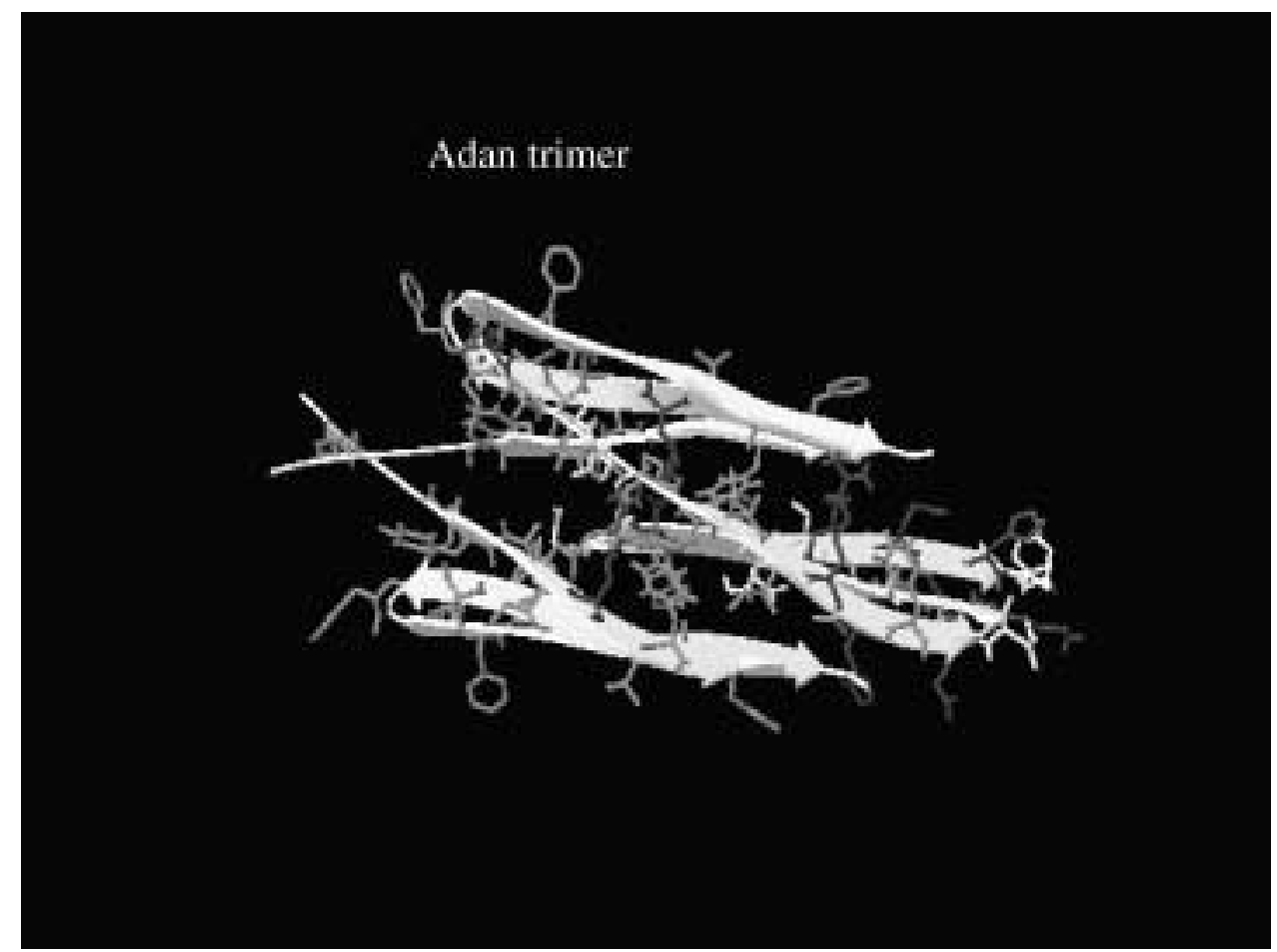

Fig. 7. Molecular model of an ADan trimer using Swiss-PDB viewer. Hydrophobic residues are green, basic residues blue and acidic red. The $\beta$-strands are recorded as yellow ribbons. 
ored green in Fig. 7) of juxtaposed molecules, with electrostatic interactions occurring between side chains of $\mathrm{Arg}^{9}$ and $\mathrm{Glu}^{12}$ in a hydrophobic environment which could provide a high degree of stabilization energy. The oligomeric states of these peptides have been found to induce apoptosis in and finally kill, neuronal cells in culture (El-Agnaf et al., 2001).

Recent studies on $\beta$-amyloid support the idea that nonfibrillar oligomeric species are pathogenic in Alzheimer's disease [14,12-22]. Studies by us and others have shown that mutant "amyloidogenic" proteins associated with inherited forms of $\beta$-amyloidosis have a greater propensity to form oligomers, in early-onset familial Alzheimer's disease or cerebrovascular amyloidosis [12-22], and $\alpha$-synuclein protein in early-onset familial Parkinson's disease [19]. Therefore, defining the conformational state of the toxic species is important for developing therapeutics for these amyloidosis disorders [17]. A stable $\beta$-structured oligomer may interact with a receptor that induces apoptosis after itself aggregating thereby inducing secondary changes which are detrimental to the neuronal cell.

\section{Acknowledgement}

We are grateful to the BBSRC and CeNeS for their support.

\section{References}

[1] C. Worster-Drought, T.R. Hill and W.H. McMenemy, J. Neurol. Psychopathol. 14 (1933), 27-34.

[2] G.T. Plant, T. Revesz, R.O. Barnard, A.E. Harding and P.C. Gautier-Smith, Brain 113 (1990), 721-747.

[3] H. Aikawa, K. Suzuki, Y. Iwasaki and R. Iiuzuka, Ann. Neurol. 17 (1985), 297-300.

[4] R. Vidal, B. Frangione, A. Rostagno, S. Mead, T. Revesz, G. Plant and J. Ghiso, Nature 399 (1999), 776-781.

[5] S.H. Kim, R. Wang, D.J. Gordon, J. Bass, D.F. Steiner, D.G. Lynn, G. Thinakaran, S.C. Meredith and S.S. Sisodia, Nat. Neurosci. 11 (1999), 984-988.

[6] R. Vidal, T. Revesz, A. Rostagno, E. Kim, J.L. Holton, T. Bek, M. Bojsen-Moller, H. Braendgaard, G. Plant, J. Ghiso and B. Frangione, Proc. Natl. Acad. Sci. USA 97 (2000), 4920-4925.

[7] O.M.A. El-Agnaf, H. Goodwin, J.M. Sheridan, E.R. Frears and B.M. Austen, Peptide \& Protein Letts. 7 (2000), 1-8.

[8] A. Tramantano, E. Bianchi, S. Venturini, F. Martin, A. Pessi and M. Sollazzo, J. Mol. Recognit. 7 (1994), 9-24.

[9] Y. Chen and B.A. Wallace, Solvent effects on the conformation and far UV CD spectra of gramicidin, Biopolymers 42 (1997), 771-778.

[10] D.M. Walsh, A. Lomarkin, G.B. Benedek, M.M. Condron and D.B. Teplow, J. Biol. Chem. 272 (1997), $22364-22372$.

[11] O.M.A. El-Agnaf, D.S. Mahil, B.P. Patel and B.M. Austen, Biochem. Biophys. Res. Commun. 273 (2000), $1003-1007$.

[12] A.E. Roher, M.O. Chaney, Y.M. Kuo, S.D. Webster, W.B. Stine, L.J. Haverkamp, A.S. Woods, R.J. Cotter, J.M. Tuohy, G.A. Krafft, B.S. Bonnell and M.R. Emmerling, J. Biol. Chem. 271 (1996), 20 631-20 635.

[13] M. Pitschke, R. Prior, M. Haupt and D. Riesne, Nature Med. 4 (1998), 832-834.

[14] D.M. Walsh, D.M. Hartley, Y. Kusumoto, Y. Fezouli, M.M. Condron, A. Lomakin, G.B. Benedek, D.J. Selkoe and D.B. Teplow, J. Biol. Chem. 274 (1999), 25 945-25 952.

[15] D.M. Hartley, D.M. Walsh, C.P. Ye, T. Diehl, P.M. Vassilev, D.B. Teplow and D.J. Selkoe, J. Neurosci. 19 (1999), 8876 8884 .

[16] J.D. Harper, S.S. Wong, C.M. Lieber and P.T. Lansbury, Jr., Biochemistry 38 (1999), 8972-8980.

[17] P.T. Lansbury, Jr., Proc. Natl. Acad. Sci. USA 96 (1999), 3342-3344.

[18] F. Saudou, S. Finkbeiner, D. Devys and M.E. Greenberg, Cell 271 (1998), 2063-2065.

[19] K.A. Conway, S.J. Lee, J.C. Rochet, T.T. Ding, R.E. Williamson and P. Lansbury, Jr., Proc. Natl. Acad. Sci. USA 97 (2000), 571-576.

[20] R. Bhatia, H. Lin and R. Lal, FASEB J. 14 (2000), 1233-1243.

[21] Y.J. Zhu, H. Lin and R. Lal, FASEB J. 14 (2000), 1244-1254.

[22] A.K. Sian, E.R. Frears, O.M.A. El-Agnaf, B.P. Patel, M.F. Manca, G. Siligardi, R. Hussain and B.M. Austen, Biochem. J. 349 (2000), 299-308. 


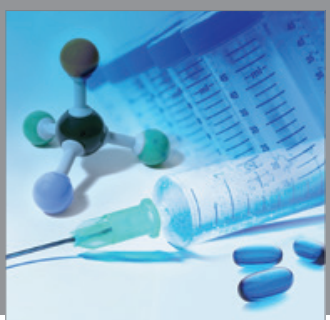

International Journal of

Medicinal Chemistry

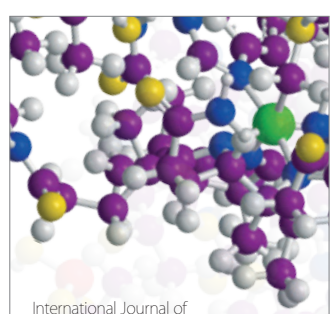

Carbohydrate Chemistry

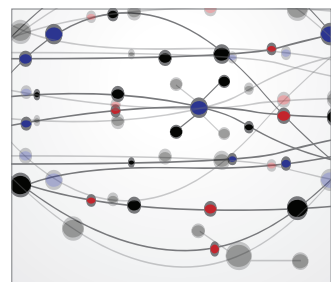

The Scientific World Journal
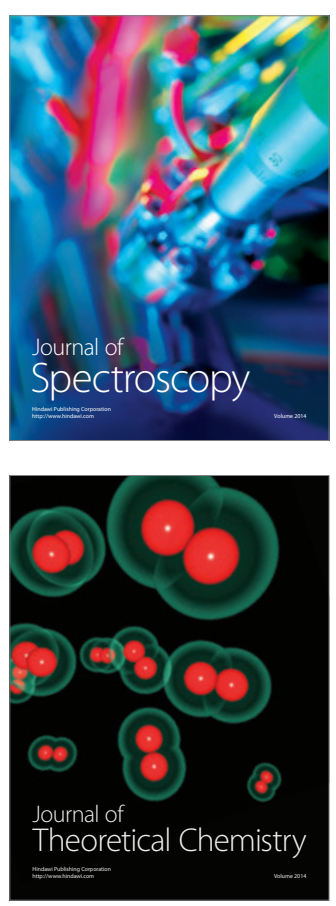
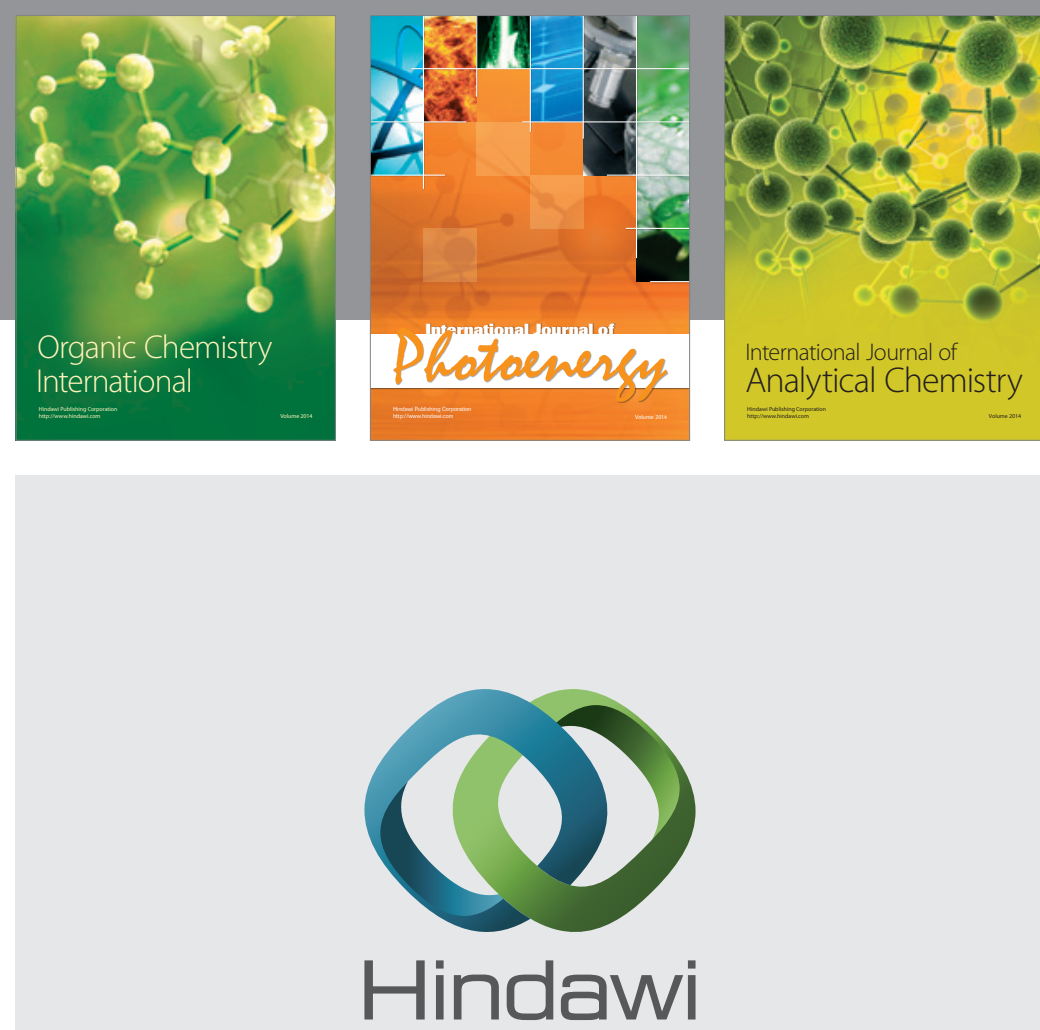

Submit your manuscripts at

http://www.hindawi.com
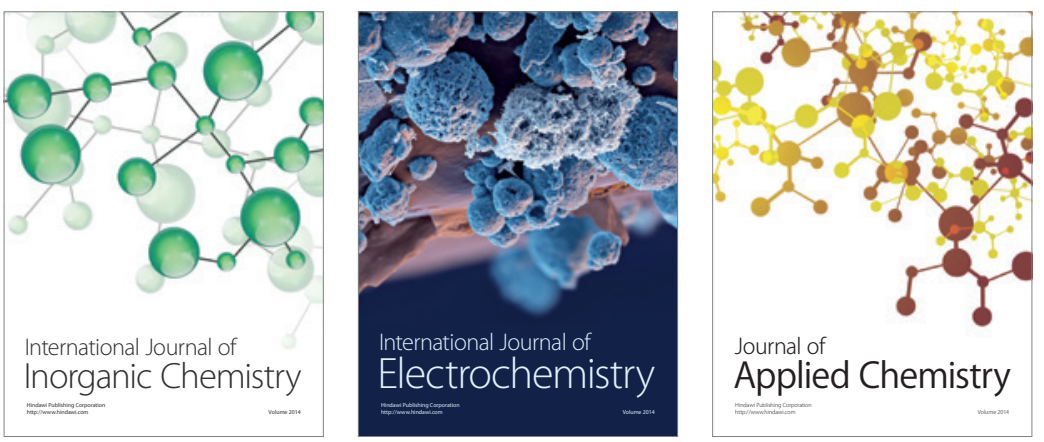

Journal of

Applied Chemistry
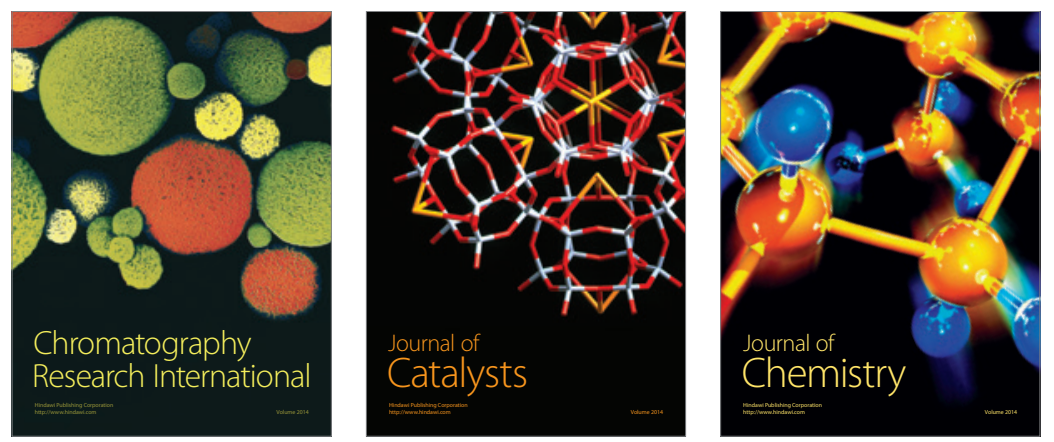
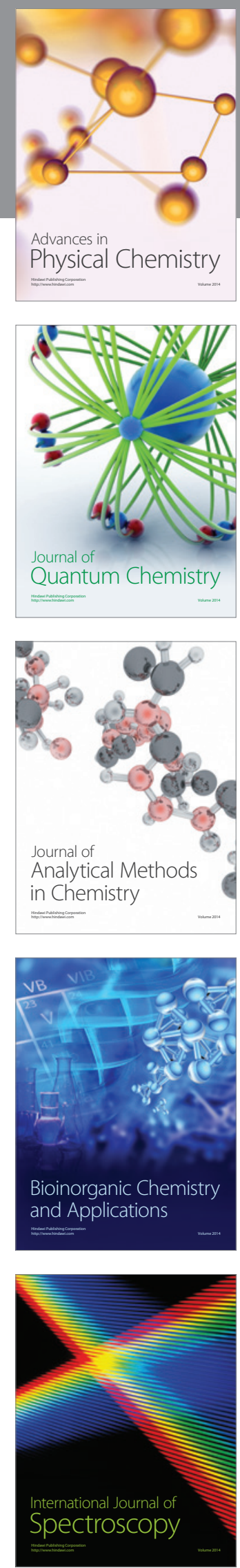